\title{
CAN POSITIVE OBLIGATIONS OF STATES SERVE AS A REMEDY FOR HUMAN RIGHTS VIOLATIONS COMMITTED BY JURISTIC PERSONS? ${ }^{1}$
}

\author{
OBRIGAÇÕES POSITIVAS DE ESTADOS PODEM SER UM MEIO DE PROTEÇÃO CONTRA \\ VIOLAÇÕES DE DIREITOS HUMANOS PRATICADAS POR PESSOAS JURÍDICAS?
}

Pavel Ondrejek ${ }^{2}$

\begin{abstract}
Positive obligations of States to protect and implement human rights are considered a part of various effects of human rights in legislations. In this article, it is argued that a crucial problem arises from the inconsistent practice of addressing violations of human rights committed by juristic persons together with a lack of underlying general theory of liability for human rights violations committed by private entities. Without a major change in the legal doctrine and case-law, we will need to remain focused on the role of the State as a guarantor of human rights, rather than on the imposition of human rights obligations on private-law entities. In this article, it is argued that the nature of the relationship between a juristic person and the State is not the only relevant aspect, as we should also examine the activity of the juristic person in question.
\end{abstract}

Keywords: Positive obligations of States. Juristic persons. State-juristic person nexus. Fundamental rights. Horizontal effect.
Resumo: Obrigações estatais positivas de proteger e de implementar direitos humanos são parte dos vários efeitos dos direitos humanos nas legislações nacionais. Neste artigo, argumenta-se que um problema crucial decorre da prática de abordar violações de direitos humanos cometidas por pessoas jurídicas sem uma teoria geral da responsabilidade por violações de direitos humanos cometidas por entidades privadas. Sem uma mudança importante na doutrina e na jurisprudência será preciso permanecer olhando apenas para o papel do Estado como garantidor de direitos humanos. Neste artigo argumenta-se que a natureza da relação entre uma pessoa jurídica e o Estado não é o único aspecto relevante. É preciso examinar também a atividade da pessoa jurídica em questão.

Palavras-chave: Obrigações positivas dos Estados. Pessoas jurídicas. Pessoas jurídicas de direito privado. Direitos fundamentais. Eficácia horizontal.

\footnotetext{
1 The article was written within Czech Science Foundation (GA ČR) project reg. No. 16-22016S 'Legal Transactions and Legal Responsibility of Juristic Persons'. An earlier version of this article was presented at the special workshop entitled 'Foundations of the Human Rights Law Architecture: Horizontal, Vertical, Territorial and Extraterritorial? Dimensions of Human Rights Obligations Reconsidered' organized by Anne Kühler and Christoph Good which took place during the IVR World Congress in Lisbon on 17th and 18th July 2017. I would like to thank the participants of the workshop for their valuable comments.

2 Lecturer at the Department of Legal Theory and Legal Doctrines, Faculty of Law, Charles University, Prague; Ovocný trh 5, Prague 1, 116 36, Czech Republic; ondrejek@prf.cuni.cz
} 


\section{Introduction}

In the comprehensive introductory part to his book concerning human rights obligations of transnational corporations, distinguished Belgian scholar Olivier de Schutter describes various circumstances that have contributed to contemporary vivid debates about the forms of responsibility borne by private corporations in respect of violations of human rights (De Schutter, 2006, pp. 1 et seq). He describes 'two waves of corporate social responsibility': after the first attempts to hold transnational corporations (TNCs) accountable in the 1970s, this agenda has again been largely discussed since the 1990s. Social transformations triggered by economic, cultural as well as legal globalisation became a major force that led both to efforts to regulate TNCs' conduct (with NGOs leading the main efforts in this field) and to prevent this kind of regulation of TNCs' conduct (obviously driven by TNCs themselves and various organised interests acting on their behalf).

De Schutter's approach corresponds to the well-known thesis of various modern schools of jurisprudence. On the one hand, system theorists, such as German legal sociologist Niklas Luhmann, describe law as a cognitively open system which interacts with its environment and changes, albeit not automatically, but according to its own self-referential (autopoietic) programmes (Luhmann, 1988, p. 20). Modern legal positivists describe law as a social fact, which means that law is a social creation or artefact (Himma, 2002, p. 126). Not only the activity of law-making bodies, but also application of law by courts and other governmental authorities has a formative character on law. ${ }^{3}$ A key source of the need to come up with a broader human rights regulation may be seen in the growing importance of businesses. ${ }^{4}$ According to the above-mentioned theories of law, even fundamental rights must respond to the social environment.

The growing importance of juristic persons is often described with reference to their wealth (Wells \& Elias, 2005, p. 147). In 2014, the gross national income of the Czech Republic, a State with more than 10.5 million inhabitants, approximately equalled the foreign assets of Vodafone Group plc (Ondřejková \& Ondřejek, 2016, p. 137). Data from 2016 show that while the GNI of the Czech Republic increased slightly, Vodafone's foreign assets fell by 25\% to USD 143 million. On the other hand, the foreign assets of the Volkswagen Group car manufacturer increased by $20 \%$ between 2012 and 2016, and the foreign assets of the food and beverages producer Anheuser-Busch InBev NV rose as much as by $81 \%$ during the same period. ${ }^{5}$ Companies' foreign assets thus change faster than those of States. ${ }^{6}$ Apart from this fact, some of the largest companies are economically stronger than some countries (the foreign assets of both Volkswagen and Anheuser-Busch now exceed the GNI of the Czech Republic). This 'financial strength' of juristic persons results in what is described in

\footnotetext{
Different types of norm creation are compared in Gardner (2012, p. 54).

See, in particular, part 2 below.

5 Data available at: <http://unctad.org/en/Pages/DIAE/World\%20Investment\%20Report/Annex-Tables.aspx>.

6 I am referring to States under 'normal' conditions - not during revolutions, civil wars, sudden serious economic crises, etc.
} 
scholarly literature as social power (Isensee, 2000, p. 610). It is not surprising that this power is used by corporations in accordance with their aim, which is to maximise profit.

De Schutter (2005, p. 314) argues that more than the sheer economic weight of corporations, their social power results from their ability to threaten governments with closing businesses and moving to a different country, which may lead to unemployment and other negative social impacts. The main aim of companies is to minimise the costs of governmental regulation concerning working conditions, environment, negotiations with trade unions, etc. Companies thus, in a certain way, promote a race among States to the bottom in human rights protection.

In my opinion, the factual power and potential pressure of TNCs on governments, together with examples of human rights violations in which private companies were involved, represent the main reasons why an adequate response was sought to also protect individuals against private corporations. Today, corporations are no longer entities behind which concrete individuals do business, which was the original reason for protecting their human rights. ${ }^{7}$ On the other hand, they may easily violate the rights of individuals. The position of the State depends on our understanding of human and fundamental rights.

In this article, I argue that a classical view of fundamental rights as spheres in which States or other entities endowed with public power cannot interfere is incomplete, if not even obsolete. Fundamental rights are more importantly related to the status of individuals who are entitled to invoke their rights before governmental bodies even if these rights were violated by another individual (Bleckmann, 1997, p. 15). ${ }^{8}$ At present, both international law and national legislations fail to adequately answer the question: Vis-à-vis which entities may individuals invoke their rights?

As Weissbrodt and Kruger (2005) argue,

during the past half-century governments have codified international human rights law protecting the rights of individuals against governmental violations. With increasing attention to the emergence of international criminal law as a response to war crimes, genocide, and crimes against humanity, there has also been growing attention to individual responsibility for grave human rights abuses. In addition, international humanitarian law and international criminal law have placed obligations on armed opposition forces engaged in non-international armed conflicts. This web of human rights obligations, however, has not paid sufficient attention to some of the most powerful non-state actors in the world: transnational corporations and other business enterprises. (p. 315).

For decades, theorists tried to find a way to fill in the possible legal vacuum created by the fact that States delegate powers to private entities or are reluctant to ensure protection of human rights in their territories. In the second part, I will illustrate the rather unsatisfactory efforts to hold private corporations accountable for human rights violations, at both the international and national

\footnotetext{
7 In Germany, this justification of the fundamental rights of juristic persons is described by the term 'Durchgriff' (penetration) of the fundamental rights of juristic persons towards natural persons (Huber, 1999, p. 2240). Big multinational corporations usually have such diverse ownership that we cannot identify any concrete persons whose human rights would be threatened in case of limitation of the rights of juristic persons (Isensee, 2000, p. 610).

8 Bleckmann (1997) argues that the aim of human rights was not only to protect individuals vis-à-vis the State, but to also ensure basic conditions for the development of a human being in democratic society.
} 
levels. In contrast, special international agreements may establish potential corporate liability for misconduct. The next part focuses on gradual broadening of the scope and dimensions of human rights since 1945. With regard to the topic of this article, particular attention will be devoted to specification of the content of positive obligations. Finally, based on these two findings, the key issue in this contribution will be addressed, specifically whether and under what conditions the extension of the States' positive obligations may serve as a remedy for violation of human rights of individuals by corporations. As an example, misconduct of private corporations in the Czech Republic will be illustrated with a view to highlighting both similarities and differences compared to the situations widely described in the scholarly literature which relate to violations of fundamental rights committed by transnational corporations in countries of the third world or during military conflicts.

\section{Unsatisfactory efforts to hold business corporations accountable for human rights violations}

The history of TNCs' obligations ensuing from violation of human rights is not easy to interpret. It is clear that much of the discussion about the need for the existence of obligations of private businesses in protection of human rights is connected with their increasing economic (Wells \& Elias, 2005, p. 147) as well as other forms of power (e.g. influence on State's policies or even politics in the forms of lobbying). Some documents, namely those issued by NGOs or even UN, advocate relatively wide accountability in this field. For instance, the document entitled UN Guiding Principles on Business and Human Rights, ${ }^{9}$ issued in 2011, contains, in its part II, principles on corporate responsibility to respect human rights, where it is asserted that "the responsibility to respect human rights is a global standard of expected conduct for all business enterprises, wherever they operate." ${ }^{10}$ These Guiding Principles followed attempts to extend the applicability of human rights from States and other public entities to private corporations, which had been made both in the academic literature and in certain soft-law documents adopted by UN, OECD (Francioni, 2011, p. 96). A brief look at the phrasing of these documents shows that they are written in somewhat vague terms and contain principles and goals, instead of specific obligations. Some more ambitious efforts, like the UN draft Code of Conduct on Transnational Corporations of 1992, have never become legally binding. This may be due to the fact that the mentioned document imposes more specific obligations upon private corporations:

\footnotetext{
9 United Nations Committee on Human Rights, Guiding Principles on Business and Human Rights. Implementing the United Nations 'Protect, Respect and Remedy' Framework. New York, Geneva: United Nations, 2011, developed by the Special Representative of the Secretary-General on the issue of human rights and transnational corporations and other business enterprises and finally endorsed by the Human Rights Council of the UN in its resolution 17/4 of 16 June 2011, available at:

<http://www.ohchr.org/_layouts/15/WopiFrame.aspx?sourcedoc=/Documents/Publications/GuidingPrinciplesBusi-

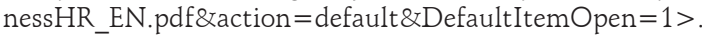

10 Ibid., p. 13.
} 
Transnational corporations shall respect human rights and fundamental freedoms in the countries in which they operate. In their social and industrial relations, transnational corporations shall not discriminate on the basis of race, colour, sex, religion, language, social, national and ethnic origin or political or other opinion. (De Schutter, 2006, p. 2).

Two important documents can be mentioned from the early stages of efforts to hold private corporations accountable for human rights violations: in 1976, OECD issued its Guidelines for Multinational Enterprises and, in the following year, ILO adopted the Declaration of Principles concerning Multinational Enterprises. Both these documents were non-binding and the procedure applicable before established national contact points can be described as 'unsatisfactory' and 'generally weak' with regard to securing protection of human rights (De Schutter, 2006, p. 8).

Another set of non-binding documents was adopted after 1990. Based on an incentive from the UN Secretary General Kofi Annan, a set of principles entitled 'Global Compact' was introduced at the 1992 World Economic Forum in Davos with the main aim of stimulating companies to voluntarily adhere to this initiative for observance of human rights and to issue their own codes of conduct (Francioni, 2011, p. 97). Furthermore, a major revision of the OECD Guidelines for Multinational Enterprises was carried out in 2000, inter alia establishing national contact points for countries that had adopted the Guidelines. ${ }^{11}$ However, the development was not straightforward towards more ambitious levels of liability of juristic persons for violation of human rights. A proposal to hold juristic persons liable for serious violations of international law was rejected during the negotiations on the Rome Statute of the International Criminal Court (De Schutter, 2005, pp. 232-233).

From a broader perspective, Francioni (2011, p. 97) rightly claims that "the project of reconceptualising human rights obligations has become problematic"; indeed, according to the current state of development of case-law and legal doctrine, juristic persons are not directly responsible for violating human rights. Francioni mentions three reasons for this: firstly, direct application of human rights norms to private actors appears to be problematic and such application would require the adoption of a new set of rules. Secondly, the courts currently do not recognise the possibility of direct application of human rights standards to private actors, and finally, the market failures over the last decade have undermined the belief in the markets' ability to generate rules that would respect public goods, including human rights. ${ }^{12}$

Reinisch (2005, p. 82) claims that direct accountability of non-governmental actors is undeveloped in human rights instruments and in international law in general. The problem with direct application of human rights to private entities can be likened to debates in post-war Germany, both in legal doctrine and among courts (Broz \& Ondřejek, 2014, p. 112). An indirect horizontal effect of fundamental rights has been recognised since 1958 and the seminal decision of the German Federal

\footnotetext{
11 The text of the Guidelines is available on the official website of OECD: <http://www.oecd.org/daf/inv/mne/48004323. pdf $>$.

12 Ibid., pp. 97-98. The last argument has been proven even more valid after the last major global financial crisis, which began in 2008.
} 
Constitutional Court in Lüth. ${ }^{13}$ Direct applicability of fundamental rights to private law relations is quite exceptional. However, the absence of a direct effect can be considered normal if one takes into account the history and objective of human rights which, since their enactment following modern democratic revolutions, have been intended to ensure protection of individuals against the State. If human rights were fully applicable in private law, this could endanger the specific principles of particular branches of law. In the extreme case, this situation could render the division of law into specific branches, such as private, administrative, business and criminal, useless and superfluous because all conflicts would be reduced to questions of fundamental rights.

Voluntary codes of conduct adopted by private corporations have also not - in my opinion - proven to be an adequate tool for strengthening the protection of human rights. The willingness of a company to issue a code of conduct is usually motivated by the anticipation of profit (e.g. by obtaining better reputation that could help it compete on the market), rather than by moral obligations or beliefs in human rights (De Schutter, 2005, pp. 260-261).

Problems concerning the application of fundamental rights to corporations and other private-law entities can be observed not only in international legal doctrine, but also in national constitutional law. During the process of adoption of the Basic Law (Grundgesetz) in post-war Germany, these discussions led to the adoption of Art. 19 (3) of the Basic Law, according to which national juristic persons would also benefit from fundamental rights protected by the Basic Law, so long as the nature of these rights allowed their application. While nothing was stated as regards juristic persons as addressees of the duties ensuing from constitutional rights, it was understood that juristic persons of public law could not become beneficiaries of fundamental rights. However, this rule was subject to certain limitations - e.g. public broadcasting corporations could benefit from freedom of speech and churches from freedom of religion (Huber, 1999, pp. 2252-2255).

The European Court of Human Rights has adopted a similar pragmatic approach with regard to juristic persons of private law as beneficiaries of fundamental rights. According to the Court's case-law, sufficient independence of the State must be proven in this regard. Thus, e.g., business corporations owned wholly or predominantly by the State are not independent and therefore cannot invoke fundamental rights for their protection (Tymofeyeva, 2015, p. 41) referring to the European Court of Human Rights case of Transpetrol v. Slovakia, application Nr. 40265/07, decision of 15 November 2013.

The example of application of fundamental rights by or against juristic persons illustrates the increasing dimensions of human rights, which can be observed in both legal theory and judicial practice. Before addressing a specific example, these various dimensions of human rights will be briefly described.

$\overline{13}$ BVerfGE, 7, 198, Lüth, Judgment of the Federal Constitutional Court of the Federal Republic of Germany, 15 January 1958. 


\section{Multiple dimensions of human rights}

Fredman (2008, p. 1) observes that, while there was long a consensus that States should not interfere with the fundamental rights of individuals, the aspect of positive actions taken by States has traditionally been connected with policies rather than with law on human rights. When the courts began acknowledging the positive obligations of States, the distinction between negative and positive duties was also described as various dichotomies - civil and political rights vs. socio-economic rights, liberty vs. equality, justiciable vs. non-justiciable rights (Fredman, 2008, p. 1). However, further judicial practice showed that these dualisms were largely artificial and at the present time, in the practice of the European Court of Human Rights, positive obligations of States are recognised within almost every right protected under the European Convention (Lavrysen, 2013, p. 162).

Positive obligations of States are not the only example of the changing human rights architecture. Horizontal effects of fundamental rights (i.e. their application in legal relations between private persons) are another example. These effects appear in several forms acknowledged by particular jurisdictions - as direct, indirect or through judicial decisions (Barak, 2001, pp. 13-41).

Another aspect, which is somewhat related, is a phenomenon referred to as constitutionalisation of law. When using this notion, I am referring to the effects of 'radiation' or 'infiltration' of human rights into various branches of law. This occurs especially in the process of interpretation of indefinite legal provisions. This 'constitutionally-conforming' method of legal reasoning means that, from among multiple various possible interpretations of relatively abstract provisions, only that or those which are compatible with human rights are taken into account.

It is obvious that many of these relatively new approaches to human rights favour judicial interpretation or even construction of law, where gaps in law are filled and law is applied, e.g. by the way of analogical reasoning (for the distinction between interpretation and construction see e.g. Potacs (2015, pp. 140-142)). This strengthening of the role of courts means primarily that they obtain a stronger position vis-à-vis other branches of government, namely the legislature and the executive. The more questions are decided by courts, the fewer such question are left for political democratic debates in the parliament. This possible shrinking of political issues in the name of human rights protection, together with the need to preserve the basic principles of the individual branches of law, should prevent extensive interpretation of the process of constitutionalisation of law although, in the contemporary 'age of rights', it is impossible to ignore the human rights aspects of any particular dispute. I nevertheless believe that this problem of reducing political debates in the name of human rights could be addressed within the re-conceptualisation of the multiple dimensions of human rights.

As I intend to focus particularly on the issues of positive obligations of States in this article, I will leave other effects of the broadening debate on human rights aside, even though a 'bigger picture' of expanding human rights could be more illustrative in some situations. 
At least in Europe, the issue of positive obligations of States is connected with the case-law of the European Court of Human Rights. In its seminal ruling in the Belgian Linguistic case, ${ }^{14}$ the Court responded to arguments put forth by the Belgian government to the effect that the Convention contains a set of negative obligations placed upon the State and thus cannot oblige the State to act with the aim to exercising the rights of individuals. The Court's interpretation of the Convention, however, acknowledged the existence of positive duties on the part of States. In paragraph 4 of its ruling, the Court stated: "In spite of its negative formulation, this provision uses the term "right" and speaks of a "right to education". Likewise, the preamble to the Protocol specifies that the object of the Protocol lies in the collective enforcement of "rights and freedoms". There is therefore no doubt that Article 2 (P12) does enshrine a right. . . The negative formulation indicates, as is confirmed by the "preparatory work", that the Contracting Parties do not recognise such a right to education as would require them to establish at their own expense, or to subsidise, education of any particular type or at any particular level. However, it cannot be concluded from this that the State has no positive obligation to ensure respect for such a right as is protected by Article 2 of the Protocol (P1-2). ${ }^{15}$ The Court connected this reasoning with Article 1 of the Convention, which requires the contracting States to secure the rights and freedoms included in it (Harris, O'Boyle, Bates, \& Bucley, 2009, p. 18).

However, subsequent case-law showed a lack of unified theory of positive obligations of the State. Lavrysen points out that the Court itself stated in 1988 that it "does not have to develop a general theory of the positive obligations which may flow from the Convention" (Lavrysen, 2013, p. 163, referring to the case of the European Court of Human Rights, Platform 'Ärzte für das Leben' $v$ Austria, application Nr. 10126/82, decision of 21 June 1988, paragraph 31). The author thinks that this approach of the Court is not satisfactory if we want to illustrate and construe a coherent theory. Constitutional theory presents several aspects of positive obligations: firstly, in view of the nature of certain rights (namely socio-economic rights), they cannot be effectively protected without action on the part of the State (provides health-care, education, social benefits, etc.); other rights (civil and political) are described as connected with positive obligations of the State, e.g. in terms of the State's due diligence (Lavrysen, 2013, p. 169), as the obligation of the State to protect and implement human rights (Bartoň et al., 2016, p. 60), in terms of protective rights (Alexy, 2002, p. 300), ${ }^{16}$ and rights connected with organisation and legal processes (Alexy, 2002, p. 314f). ${ }^{17}$

These functions of positive obligations can be further categorised and distinguished according to their relation to procedural law (e.g. obligation of the State to investigate and punish those who commit crimes that violate fundamental rights or to provide a procedure for compensa-

\footnotetext{
14 European Court of Human Rights, case 'relating to certain aspects of the laws on the use of languages in education in Belgium' v. Belgium, applications nr. 1474/62; 1677/62; 1691/62; 1769/63; 1994/63; 2126/64, decision of 23 July 1968.

15 Ibid., para 4.

16 According to Alexy (2002), protective rights are those rights which their holder has vis-à-vis the State and which protect him from interference by third parties.

17 These rights cover not only the rights to enact and provide for the performance of administrative and judicial processes, but also the rights to regulate of basic concepts of private law (marriage, inheritance...), organise broadcasting, education, etc.
} 
tion of the victims of a crime) or substantive law (e.g. the duty of the State to adopt a certain regulation which will proscribe certain conduct) (Bartoň et al., 2016, p. 61). In situations where juristic persons violate the fundamental rights of individuals, we can identify various positive obligations of States through abstraction and classification of types of cases in which a violation of a human right can be found.

\section{Positive obligations of States for violations of human rights committed by juristic persons}

In a short comparative analysis, Hoppe (2011, p. 111f) presented the approaches of three international judicial or quasi-judicial bodies, specifically the European Court of Human Rights, the Human Rights Committee interpreting the International Covenant on Civil and Political Rights (ICCPR), and the Inter-American Court on Human Rights. She focused on two human rights - the right to life and the prohibition of torture, cruel and inhuman treatment - both of which are contained in the European and American Conventions on Human Rights and in the ICCPR. The scope of her study was restricted to observing only cases involving private military and security companies (PMSC).

Even in such a narrow selection of cases, there are certain differences in the interpretation of the positive obligations of States ensuing from the above-mentioned rights. I will nevertheless try to extrapolate certain general types of positive obligations which follow from case-law and doctrine that, in my opinion, might also be applicable to a certain degree in the legal relations of other private persons, at least from an analytical point of view. However, specific lines of interpretation influenced by other contextual factors should be taken into account in practice. According to some theories, the specific form of positive obligations of a State is even determined by the perception of law or world views of individual judges who hear and decide individual cases. ${ }^{18}$

As pointed out by Francioni and other authors, certain situations may occur where the conduct of a juristic person can be attributed directly to the State. These situations are identified in Articles 5 and 8 of the draft Articles on Responsibility of States for Internationally Wrongful Acts adopted by the International Law Commission in 2001. Under the Articles, the conduct of a juristic person may be attributable to the State: a) if a private entity either exercises elements of governmental authority (Art. 5) or b) if it acts on the instruction of or under the direction or control of the State (Art. 8) (Francioni, 2011, pp. 100-104; Pinzauti, 2011, p. 153). ${ }^{19}$

A different set of obligations of the State relates to the principle of effective protection of human rights within its territory; it follows that the State must exercise reasonable control over

\footnotetext{
18 A view which is endorsed by the proponents of legal realism - see e.g. Leiter (2010, p. 249).

19 The text of the above-mentioned draft Articles can be found on the International Law Commission's website, available at <http://legal.un.org/ilc/texts/instruments/english/draft_articles/9_6_2001.pdf > .
} 
compliance with human rights standards. ${ }^{20}$ In a situation where there is no unity as to the extent of positive obligation of States, it seems useful to mention a further two situations in which a juristic person may appear and point out the differences between them. Firstly, there may exist a nexus between the State and a corporation - e.g. if the State wholly or partially owns a juristic person, if a juristic person receives the State's guarantee, financial support, etc. (United Nations Committee on Human Rights, 2011, p. 6). The second category concerns situations where juristic persons neither perform any of the State's functions nor is there any nexus with the State. The reason why it is important to distinguish between various categories of juristic persons and their relations to the State lies in the fact that, in my opinion, the State's duties differ in each of these situations.

As follows from case-law, different positions of juristic persons lead to different scopes of positive obligations of the State. The European Court of Human Rights acknowledges the existence of positive obligations of the State in cases where the State (governmental authorities): "a) knew or ought to have known of a real and immediate risk that a violation can be committed and $b$ ) failed to take measures within their power to avoid that risk." (Pinzauti, 2011, p. 154, quoting European Court of Human Rights, Osman v. U.K., application Nr. 23452/94, decision of 28 October 1998). At the same time, however, the Court interpreted the scope of positive obligations so "as not to impose on states an impossible or disproportionate burden: they are only required to take measures within their powers, and that, judged reasonably, might have been expected to avoid the occurrence of a given violation of the Convention" (Pinzauti, 2011, p. 158). The key question to be answered is: what should the State have known in terms of violation of fundamental rights by a private party? In my opinion, the answer to this question differs according to the situation of the juristic person and its relation to the State. But there are also further criteria other than the nature of the legal relationship between the State and the juristic person. Some of them will be illustrated on specific examples in the Czech Republic.

\section{4 'Crooks' and other cases in the Czech Republic and the scope of the positive obligation of States}

No private military and security companies, such as Blackwater in Iraq, operate in the region of Central Europe, nor do we witness any grave violations of standard working conditions like in the developing countries of Africa or Asia. Companies do not maintain control over any particular territory like Royal Dutch Shell company which, in co-operation with the Nigerian military, supressed local resistance to oil extraction practices in Ogoniland (Wells \& Elias, 2005, p. 144).

Despite this fact, debates arise from to time on the subject of accountability of corporations, especially in terms of violation of the rights of employees, the rights of consumers and the

$\overline{20}$ Francioni (2011, p. 110) argues that international human rights law requires States to exercise sovereignty in such a way as to reasonably prevent activities conducted in their territory from causing human rights violations to other people. 
rights of an affected population. Violation of the rights of employees in the Czech Republic can be illustrated on the publicly leaked internal document of the Lidl chain of supermarkets, regulating additional bathroom breaks for women cashiers during menstruation. ${ }^{21}$

The second example from the Czech Republic relates to violation of the rights of the affected population in the city of Ostrava (a city with about 300,000 inhabitants situated in the industrial part of the Czech Republic), where large steelworks are located near the city centre. In this case, claimants living close to the factory sued the company for constant air pollution. The fundamental right to a healthy environment as well as the right to life were affected, as the polluted area houses a disproportionately high number of oncological patients.

Another highly publicised case of violation of rights occurred in the area of consumer protection. In 2012, a documentary film called Šmejdi (in English, "Crooks") triggered a broad debate concerning the role of corporations specialising in product presentation (and selling) events.

The film showed unfair, manipulative and sometimes even coercive practices that these companies use in order to force elderly citizens to buy their products. These products (kitchenware, mattresses, electrical appliances for households, etc.) are usually of poor quality and sometimes priced more than ten times above their actual market value. The product presentation events are organised exclusively for elderly people who are more vulnerable to manipulative techniques and sometimes get confused by company dealers who make them sign a contract that they would otherwise never accept. The most shocking fact in this case was that the companies intentionally aimed their product presentation events at older people, taking advantage of their social isolation and willingness to join what was often described to them as a cultural event.

Shortly after the premiere of the film, the Czech Consumer Protection Act was amended to extend the powers of the Czech Trade Inspection Authority and impose further duties on the organisers of these selling events.

All the above-mentioned examples beg two questions: Firstly, were the fundamental rights of these people affected? And the second question: Should the State be held liable for the misconduct of private corporations?

As concerns fundamental rights, the second example is clear since the Czech Charter of Fundamental Rights and Freedoms comprises both the right to the protection of health and the right to a favourable environment (in Articles 31 and 35, respectively). The first and the third examples both relate primarily to private-law contracts (between employers and employees, between entrepreneurs and consumers). However, several arguments can be made as to why these cases also pertain to fundamental rights. The first lies in a gross imbalance between the two parties, while the second concerns the massive abuse of the stronger position which led to violation of rights relating

21 Available at: <http://zpravy.idnes.cz/obchod-chtel-oznacit-pokladni-s-menstruaci-f2o-/domaci.aspx?c=A040728_213047_ domaci_mad $>$. 
to the dignity and personality of the weaker party. In the case of Lidl, this was a duty imposed on women cashiers to wear a headband and thus expose one of the most intimate spheres of their lives. In the case of "Crooks", this lies in massive coercion and manipulation, which not only renders the contracts invalid and might even be assessed as criminal practice, but the humiliation of elderly people and their 'objectification' also interfered with their freedom, dignity and personal rights.

The search for an answer to the second question, i.e. the scope of the State's positive obligation leads us back to the issue of due diligence on the part of the State, which should simultaneously not impose an unreasonable burden.

The first and third examples have in common that they concern primarily private-law relations (between buyers and sellers and between employers and employees). What is the criterion of due diligence here? In my opinion, it should relate to the knowledge of governmental authorities of the conduct of private persons. Hoppe (2011, p. 113) argues that as concerns PMSCs, repeated violation of human rights increases the duty of the State. I consider that stricter demands would lead to undesired extension of the State's control and its intrusion into private legal relations.

The second of the mentioned examples relates to State control within public-law regulation. Due diligence is certainly higher in this case and is set by legal rules (in this example, rules on pollution control). The nexus might also be closer if the corporation received State subsidies or guarantees, or if it had contracts with the State. In all these situations, a policy of no human rights violations committed by the corporation should be strictly demanded by the State.

\section{Conclusion}

In line with Francioni (2011, p. 98), it can be argued that under the current circumstances and without a major change in jurisprudence and case-law, we need to remain focused on the role of the State as a guarantor of human rights, rather than on imposing human rights obligations on entities of private law. When a private juristic person violates a fundamental right, several situations can occur: if the juristic person performs the functions of the State or acts on the instruction of or under the direction or control of the State, then its conduct is attributable to the State directly and no positive obligation arises.

In other situations, the scope of positive obligations varies depending on a number of factors, most often on the nexus between the State and the juristic person - a broader scope is presumed in case of closer relations stemming from State ownership or on the basis of a certain form of contractual relationship between the juristic person and the State.

Finally, if there is no link between the State and the juristic person, the State's duty to prevent violation of fundamental rights by a private entity must be interpreted in such a way as not to impose an unreasonable burden on the State and its duty to provide control and oversee transactions among private persons. On the other hand, as shown in the examples from the Czech Repu- 
blic, juristic persons occasionally violate the rights of vulnerable groups (elderly people, employees) where specific, even preventive, powers of competent authorities of the State should be enacted. In case of an already reported violation of fundamental rights, positive obligations of the State to legislate on and control the observance of laws should be increased. To conclude, the nature of the relationship of a juristic person to the state is not the only relevant aspect as we also scrutinise the activities of the juristic person in question.

\section{References}

Alexy, R. (2002). A Theory of Constitutional Rights. Oxford: Oxford University Press.

Barak, A. (2001). Constitutional Human Rights and Private Law. In D. Friedman \& D. Barak-Erez (Eds.), Human Rights in Private Law (pp. 13-42). Oxford, Portland: Hart Publishing.

Bartoň, M., Kratochvíl, J., Kopa, M., Tomoszek, M., Jirásek, J., Svaček, O. (2016). Základní práva (Fundamental Rights). Prague: Leges.

Bleckmann, A. (1997). Staatsrecht. Volume 2 - Grundrechte (4 ed). Köln, Berlin, Bonn, Munich: Carl Heymanns Verlag.

Broz, J. \& Ondřejek, P. (2014). Human Rights Limits on State Power. In J. Kysela (Ed.). The State as a Giant with Feet of Clay (pp. 101-120). Frankfurt am Main: Peter Lang.

BVerfGE, 7, 198, Lüth, Judgment of the Federal Constitutional Court of the Federal Republic of Germany, 15 January 1958.

De Schutter, O. (2005). The Accountability of Multinationals for Human Rights Violations in European Law. In P. Alston (Ed.), Non-State Actors and Human Rights (pp. 227-314). Oxford: Oxford University Press.

De Schutter, O. (2006). The Challenge on Imposing Human Rights Norms on Corporate Actors. In O. De Schutter (Ed.), Transnational Corporations and Human Rights (pp. 1-39). Oxford: Hart Publishing.

European Court of Human Rights. Case 'relating to certain aspects of the laws on the use of languages in education in Belgium' v. Belgium, applications Nr. 1474/62; 1677/62; 1691/62; 1769/63; 1994/63; 2126/64, decision of 23 July 1968.

European Court of Human Rights. Osman v. U.K., application Nr. 23452/94, decision of 28 October 1998.

European Court of Human Rights. Platform 'Ärzte für das Leben' v Austria, application Nr. 10126/82, decision of 21 June 1988.

European Court of Human Rights. Transpetrol v. Slovakia, application Nr. 40265/07, decision of 15 November 2013. 
Francioni, F. (2011). The Role of the Home State in Ensuring Compliance with Human Rights by Private Military Companies. In F. Francioni \& N. Ronzitti (Eds.), War by Contract. Human Rights, Humanitarian Law and Private Contractors (pp. 93-110). Oxford: Oxford University Press.

Fredman, S. (2008). Human Rights Transformed. Positive Rights and Positive Duties. Oxford: Oxford University Press.

Gardner, J. (2012). Law as a Leap of Faith. Oxford: Oxford University Press.

Harris, D., O'Boyle, M., Bates, E. P., \& Bucley, C. M. (2009). Law of the European Convention on Human Rights (2 ed). Oxford: Oxford University Press.

Himma, K. E. (2002). Inclusive Legal Positivism. In J. Coleman \& S. Shapiro (Eds.), The Oxford Handbook Jurisprudence and Philosophy of Law (pp. 125-165). Oxford: Oxford University Press.

Hoppe, C. (2011). Positive Human Rights Obligations of the Hiring State in Connection with the Provision of 'Coercive Services' by a Private Military or Security Company. In F. Francioni \& N. Ronzitti (Eds.), War by Contract. Human Rights, Humanitarian Law and Private Contractors (pp. 111-129). Oxford: Oxford University Press.

Huber, P. M. (1999). Artikel 19. In H. von Mangoldt, F. Klein \& Ch. Starck (Eds.), Das Bonner Grundgesetz. Kommentar. Band 1 (4 ed) (pp. 2174-2336). Munich: Franz Vahlen.

Isensee, J. (2000). Anwendung der Grundrechte auf juristiche Personen, In J. Isensee \& P. Kirchhof (Eds.), Handbuch des Staatsrechts. Band V. Allgemeine Grundrechtslehre (2 ed) (pp. 563-616). Heidelberg: C.F.Müller.

Lavrysen, L. (2013). The Scope of Rights and the Scope of Obligations. In E. Brehms \& J. Gerards (Eds.), Shaping Rights in the ECHR. The Role of the European Court of Human Rights in Determining the Scope of Human Rights (pp. 162-182). Cambridge: Cambridge University Press.

Leiter, B. (2010). American Legal Realism. In D. Patterson (Ed.), A Companion to Philosophy of Law and Legal Theory (2 ed.) (pp. 249-266). Malden: Blackwell Publishing.

Luhmann, N. (1988). The Unity of the Legal System. In G. Teubner (Ed.), Autopoietic Law: A New Approach to Law and Society (pp. 12-35). Berlin, New York: Walter de Gruyter.

Ondřejková, J. \& Ondřejek, P. (2016). Globalizace, stát a právo (Globalization, State and Law). In J. Kysela \& P. Ondřejek (eds.), Kolos na hliněných nohou? K proměnám státu a jeho rolí (Giant with Feet of Clay? Transformations of a State and Its Roles) (pp. 130-149). Prague: Leges.

Pinzauti, G. (2011). Adjudicating Human Rights Violations Committed by Private Contractors in Conflict Situations before the European Court of Human Rights. In F. Francioni \& N. Ronzitti (Eds.), War by Contract. Human Rights, Humanitarian Law and Private Contractors (pp. 149-170). Oxford: Oxford University Press.

Potacs, M. (2015). Rechtstheorie. Wien: Facultas.

Reinisch, A. (2005). The Changing International Legal Framework for Dealing with Non-State Actors. In P. Alston (Ed.), Non-State Actors and Human Rights (pp. 37-89). Oxford: Oxford University Press. 
Tymofeyeva, A. (2015). Non-Governmental Organisations under the European Convention on Human Rights. Exceptional Legal Standing. Waldkirchen: rw\&w Science \& New Media Passau, Berlin, Prague.

United Nations Committee on Human Rights (2011). Guiding Principles on Business and Human Rights. Implementing the United Nations 'Protect, Respect and Remedy' Framework. New York, Geneva: United Nations.

Weissbrodt, D. \& Kruger, M. (2005). Human Rights Responsibilities of Businesses as Non-State Actors. In P. Alston (Ed.), Non-State Actors and Human Rights (pp. 315-350). Oxford: Oxford University Press.

Wells, C. \& Elias, J. (2005). Catching the Conscience of the King: Corporate Players on the International Stage. In P. Alston (Ed.), Non-State Actors and Human Rights (pp. 141-176). Oxford: Oxford University Press.

Data da submissão: 15 de fevereiro de 2018 Aceito em: 15 de abril de 2018 
